\title{
Moderating Effects of Additional Mathematics' Achievement During SPM on the Relationship Between Performance in Modern Mathematics and Mathematical Errors Occurrences: A Case Study of MDAB Students in UiTM Melaka
}

Siti Fairus Fuzi, Wan Hartini Wan Hassan, Siti Nursyahira Zainudin, Siti Ramizah Jama, Nurul Emyza

Zahidi and Bushra Abdul Halim ${ }^{*}$

Universiti Teknologi MARA Cawangan Melaka, 78000 Alor Gajah, Melaka, Malaysia

\begin{abstract}
This study was intended to identify nine types of mathematical errors with $20 \%$ and more occurrences made by students when answering Intensive Mathematics final examination paper.From the findings, it can be concluded that the exhibition of concept errors and transformation errors were both significantly different across performance levels in Modern Mathematics and Additional Mathematics. Both concept and transformation errors were more obvious among those less performing students. However, the exhibition of comprehension errors, number operation errors and factoring errors were approximately similar across the performance levels of Modern Mathematics and Additional Mathematics. For random, calculation and number form conversion errors, there were significant differences in committing the errors across performance levels in Modern Mathematics. Meanwhile, there were similarities in making random, calculation and number form conversion errors across performance levels in Additional Mathematics. Results also revealed that students who did not learn Additional Mathematics during secondary school exhibited significantly more concept errors, comprehension errors, expanding errors and transformation errors than students who learnt the subject in school. It is also concluded that the dummy variable, taking or not taking Additional Mathematics moderates the relationship between Modern Mathematics' grade point and total occurrences of exhibiting mathematical errors.
\end{abstract}

Keywords: Sijil Pelajaran Malaysia (SPM), Modern Mathematics, Additional Mathematics, mathematical errors, Mengubah Destini Anak Bangsa (MDAB) programme

\section{INTRODUCTION}

Modern Mathematics is one of the core subjects during SPM. It is a compulsory subject and students must obtain at least a pass for the subject in SPM. A pass in the subject is very important since it is the basic requirement to pursue their study to tertiary education. On the other hand, Additional Mathematics is an optional subject for SPM. Therefore, students are given an option whether take or not to take the subject during SPM. It is very crucial for students to be skilful in Mathematics especially to those who are pursuing their studies in the tertiary education in the field of science and technology, management sciences and social sciences.

When solving mathematical problems, some students frequently make mathematical errors. Even having early exposure to basic mathematics in school, this problem seems to arise at tertiary level especially to groups of prediploma students, which in UiTM is commonly known as MDAB. From SPM results, it was found that the performance of MDAB students in Modern Mathematics ranges from below average to average grades. Majority of the students did not sit for Additional Mathematics during SPM. Even if they took the subject, many failed the subject

*Corresponding author's e-mail: *bushra270@uitm.edu.my 
with grade G. For this group of students, when answering mathematics questions, they frequently make mistakes or errors. Therefore, it is important to investigate whether taking or not taking Additional Mathematics during SPM has an effect in committing mathematical errors in answering mathematics question.

\section{LITERATURE REVIEW}

A study by Siti Balqis et. al., (2017) revealed that Modern Mathematics grade points influenced the marks obtained in mathematics examination. They further reported that the most prevalent error committed by students is expanding error. Failure in mastering basic mathematical concepts is one of the reasons why students always make mistakes in solving mathematical problems as reported by Muhammad Dliwaul (2014). Maisurah et. al., (2014) also agreed that concept errors are the most frequent mathematical errors made among students when solving mathematics questions.

According to Siti Aishah and Noor 'Aina (2005), errors rooted from misunderstandings of basic mathematical concepts such as using wrong technics and applying wrong formula. Azrul Fahmi and Mazlina (2007) further reported that mastering basic algebra concepts are essential particularly in expansion and factorization which are very much needed in high level mathematical solving problems. There are students who face difficulties with number operations with negative numbers, expanding algebraic expressions with powers and simplifying algebraic terms (Norhidayah and Md Nor, 2007). Meanwhile, Ilmi Fitroh (2011) concluded that many students had problems in basic operations of addition, subtraction, multiplication or division of either numbers or algebraic expressions. As reported by Ismail and Awang (2008), students' performance in colleges and universities is significantly dependent on their mathematics achievements during schools.

Conceptual understanding and procedural knowledge are essential in problem solving skills as stated by Geary (2004). Students with difficulties in solving mathematical problems would most probably make similar repeated errors as stated by Nik Azis (2008). Latha (2007) further noted that students are weak in understanding basic arithmetic and mathematical concepts. Due to this reason, they make errors as they are lacking in procedure and arithmetic knowledge. Some students have difficulties in making accurate perceptions and interpretations, memorizing and retrieving facts, giving concentrations and using their logical thinking. According to Zahara et. al., (2009), Ismail (2009) and Andersson and Lyxell (2007), these difficulties would affect the students in learning mathematics and hence resulting in making a lot of mathematical errors. Difficulties in thinking could also affect decision making during problem-solving activity that would consequently lead to deterioration in mathematics achievement (Miranda, 2006).

\section{CONCEPTUAL FRAMEWORK}

Based on research done previously, Mohd Zulfabli and Siti Salwa (2014) conducted a study in comparing SPM Mathematics results with a course on Mechanical Engineering programs namely Thermodynamics 1 (JJ207). They found that there was a very strong significant relationship between SPM results and the student's performance in the subject taken in diploma. Thus, the conceptual framework of this study is presented in Figure 1 where the dependent variable is the number of occurrences of mathematical errors which is ratio-scaled. Meanwhile the independent variables are; i) Additional Mathematics subject which is recoded as dummy variable (o - did not take Additional Mathematics and 1 - took Additional Mathematics), which is categorical and, ii) Modern Mathematics grade points which is ratio-scaled.

All questions of MATo37 final examination April 2016 scripts belonged to 153 MDAB students in UiTM Cawangan Melaka were analysed and data of errors were observed and recorded by using observation method. Based on

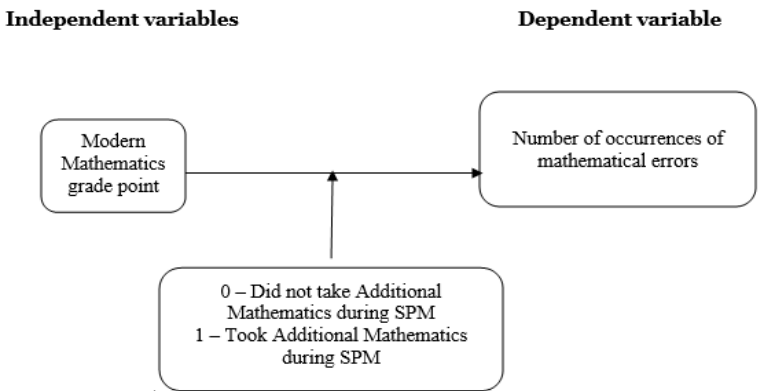

FIG1 : Conceptual Framework of the Study

\section{METHODOLOGY}

The first mathematical error found for each answered item question in each script, the type of mathematical errors was 
identified. The identified types of mathematical errors were described or defined to ease the data collection and data analysis processes are listed in Table I.

TABLE I : Description of Type of Mathematical Error

\begin{tabular}{|c|c|c|}
\hline No. & $\begin{array}{l}\text { Type of } \\
\text { Mathematical } \\
\text { Errors }\end{array}$ & $\begin{array}{l}\text { Description of the } \\
\text { Mathematical Errors }\end{array}$ \\
\hline 1 & $\begin{array}{l}\text { Number } \\
\text { operations }\end{array}$ & $\begin{array}{l}\text { Error due to mathematical } \\
\text { operations - BODMAS rule (( ), } \\
\div, \times,+,-)\end{array}$ \\
\hline 2 & Calculation & Error when using calculator. \\
\hline 3 & Comprehension & $\begin{array}{l}\text { Error in understanding question } \\
\text { or the language used. }\end{array}$ \\
\hline 4 & Concept & $\begin{array}{l}\text { Error in basic facts that involves } \\
\text { rules, laws or definitions }\end{array}$ \\
\hline 5 & Factoring & Error in finding common factors. \\
\hline 6 & Expanding & $\begin{array}{l}\text { Error in multiplying algebraic } \\
\text { expressions. }\end{array}$ \\
\hline 7 & $\begin{array}{l}\text { Random } \\
\text { (plotting graph, } \\
\text { carry forward, } \\
\text { do not simplify } \\
\text { answer, no units } \\
\text { written, do not } \\
\text { write down the } \\
\text { answer) }\end{array}$ & $\begin{array}{l}\text { Error emerges when collecting } \\
\text { data such as error in sketching } \\
\text { graph, error due the previously } \\
\text { related question, error to } \\
\text { simplify the answer, error of not } \\
\text { writing the units and error in not } \\
\text { writing the final answer. }\end{array}$ \\
\hline 8 & $\begin{array}{l}\text { Number form } \\
\text { conversion }\end{array}$ & $\begin{array}{l}\text { Error in converting percent to } \\
\text { fraction, decimal to fraction or } \\
\text { vice versa. }\end{array}$ \\
\hline 9 & Transformation & $\begin{array}{l}\text { Error in transforming the } \\
\text { numbers and variables as the } \\
\text { subject of the formula. }\end{array}$ \\
\hline
\end{tabular}

Students' Mathematics' achievement during SPM is measured by obtaining their Modern Mathematics and Additional Mathematics results. Students' achievement in Modern Mathematics is categorized as excellent (A and A+), distinction (B, B+, C and $\mathrm{C}+$ ) and pass (D and $\mathrm{E}$ ). No failure was recorded for this subject. As for Additional Mathematics, it is categorized as took and passed, took and failed and did not take the subject since majority of them do not take the subject during SPM.

An analysis of variance (ANOVA) for each nine types of mathematical errors across achievement levels for both Modern Mathematics and Additional Mathematics was conducted to measure any similarities or differences in committing the errors. An independent t-test was used to examine any significant difference between students who took and did not take Additional Mathematics during SPM in committing mathematical errors. Then, moderated regression analysis was used to moderate the effects of the Additional Mathematics on the relationship between performance level in Modern Mathematics and number of mathematical error occurrences.

\section{RESULTS AND DISCUSSIONS}

\section{A. Descriptive Statistics of Types of} Mathematical Errors Committed by the respondents

From the nine most frequent occurring errors, the descriptive statistics was performed for each type of mathematical errors. From the analysis, concept error recorded the highest mean $(M=4.24)$ that vary from 0 to 17 errors. Meanwhile, random error recorded the second highest mean $(\mathrm{M}=3.48)$, ranging from $\mathrm{O}$ to 14 errors committed by the respondents. The third highest number of mean is comprehension error $(M=1.76)$ with errors vary from o to 18 errors.

During SPM, 69.9\% of the respondents scored Modern Mathematics with a pass grade of D and E, while $25.5 \%$ students scored a distinction in the subject and only $4.6 \%$ students obtained excellent results. As for the MATo37 final examination paper, the average score obtained was 71.33 that ranged from 14 until 100 marks. The students with excellent grades during SPM scored on average of 88.57 marks that ranged from 64 to 97 marks. As for students with distinction grades in Modern Mathematics during SPM, they scored at average of 85.79 marks ranged from 53 to 100 marks while $50 \%$ of the students obtained marks of more than 87.5. As for students with pass grades during SPM, the average score for MATo37 paper was 64.93 marks that ranged from 14 to 98 marks. Meanwhile, for the total number of mathematical errors, the excellent group of students made 8.71 errors that ranged from 3 to 29 errors. Meanwhile, those with distinction grades committed on average of 11.28 mathematical errors ranged from 1 to 28 errors. As for students with pass grades, they gained on average of 23.88 mathematical errors ranged from 4 to 45 errors. From these results, it can be concluded that students who scored excellent results in Modern Mathematics in SPM committed less errors that those who did not perform 
during SPM in answering MATo37 examination paper.

As for Additional Mathematics, $70.6 \%$ of the respondents did not take Additional Mathematics for SPM. Only $\mathbf{2 9 . 4 \%}$ of the respondents took the subject for SPM. Of those taking the subject, $51.1 \%$ passed the subject. The students who passed the subject achieved an average of 90.85 marks for MATo37 final examination paper and exhibited at average of 8 mathematical errors. On the other hand, students who took and failed the subject scored at average of 79.89 marks for MATo37 final examination paper and committed approximately at average of 16 mathematical errors. Meanwhile, the students who did not take Additional Mathematics obtained on average of 65.43 marks for MATo37 final examination paper and made approximately 23 mathematical errors.

\section{B. $\quad$ Similarities and Differences of Types of} Mathematical Errors Exhibited Across Performance

Levels of Modern Mathematics (Excellent, Distinction, Pass) and Across Additional

\section{Mathematics (Take and Do Not Take)}

Based on the analysis of the similarities and differences of types of mathematical errors exhibited across Modern Mathematics performance levels, the findings revealed that there were similarities in exhibiting comprehension, factoring errors and expanding errors among the respondents. Findings also conclude that regardless of students' performances in Modern Mathematics during SPM, students still exhibited comprehension, factoring and expanding errors. However, there were significant differences in committing number operation errors, calculation errors, concept errors, random errors, number form conversion errors and transformation errors among students. Using post hoc analysis, results revealed that there were significant differences in exhibiting calculation errors between excellent-pass and distinction-pass groups of students ( $\mathrm{p}=0.020)$, concept errors between distinctionpass groups of students $(\mathrm{p}=0.049)$ and transformation errors between excellent-pass $(\mathrm{p}=0.008)$ groups of students.

Results showed that there were similarities in exhibiting number operation error, calculation error, comprehension error, factoring error, random error and number form conversion among students across performance levels of Additional Mathematics. However, there were significant differences in exhibiting concept error, expanding error and transformation error among students across performance levels of Additional Mathematics. Using post-hoc analysis, findings showed that concept errors differed significantly among students who took and passed and those students who did not take Additional Mathematics ( $p=0.022$ ) during SPM. Meanwhile, transformation error differed significantly among students who took and passed and those students who did not take the subject $(\mathrm{p}=0.034)$.

Thus, it can be concluded that the exhibition of concept error and transformation error are both significantly different across performance levels in Modern Mathematics and Additional Mathematics. Both concept and transformation errors were obvious among those less performed students. However, the exhibition of comprehension error and factoring error were approximately similar across the performance levels of Modern Mathematics and Additional Mathematics. For random, calculation and number form conversion errors, there were significant differences in committing the errors between performance levels in Modern Mathematics. Meanwhile, there were similarities in making random, calculation and number form conversion errors across performance levels in Additional Mathematics. As for expanding error, there were similarities in exhibiting the errors across performance levels of Modern Mathematics. In contrast, the errors were more rampant among those who did not take Additional Mathematics group of students.

\section{Differences of Committing Types of}

\section{Mathematical Errors between Students Taking or}

\section{Not Taking Additional Mathematics during SPM}

The analysis results revealed that students who did not take Additional Mathematics $(M=2.06)$ during SPM made significantly $(\mathrm{t}=3.284 ; \mathrm{p}<0.05)$ more comprehension errors than students who took the subject $(M=1.04)$ during SPM. It was also found that students who did not take Additional Mathematics (mean $=4.81$ ) committed significantly $(\mathrm{t}=3.374 ; \mathrm{p}<0.05)$ more concept errors than students who took the subject (mean $=2.89$ ). As for making more expanding errors, it was noticed that students who took Additional Mathematics $(\mathrm{M}=0.20)$ made significantly $(t=3.082 ; p<0.05)$ less of this kind of error than those who did not take the subject $(\mathrm{M}=0.40)$. Results also revealed that students who did not take Additional Mathematics $(\mathrm{M}=0.69)$ during SPM exhibited significantly $(\mathrm{t}=2.568 ; \mathrm{p}<0.05)$ more transformation errors than 
students who took the subject $(\mathrm{M}=0.42)$ during SPM. However, there were no differences in exhibiting number operation errors, calculation errors, factoring errors and random errors between these two groups of students.

\section{Moderating Effects of Additional}

\section{Mathematics on the Relationship between Modern}

Mathematics and Mathematical Error Occurrences

Moderated regression analysis was used to study the moderating effects of Additional Mathematics on the relationship between Modern Mathematics' grade points and total occurrences of mathematical errors.

First, the Additional Mathematics' dummy coded variable and the centred Modern Mathematics' grade points were set in. Model summary Table II shows that these variables accounted for a significant amount of variance in total occurrences of mathematical errors $(\mathrm{F}(2,150)=$ 37.108, $\mathrm{p}<0.01)$. At the second step, the interaction term (centred Modern Mathematics' grade point $\times$ Additional Mathematics' dummy coded) was set. At this step, the interaction term accounted for a significant proportion of the variance in total occurrences of mathematical errors ( $F$ change $(1,149)=7.820, \mathrm{p}=0.006, \mathrm{~B}=12.012$, $\mathrm{t}(149)=$ 2.797, $\mathrm{p}<0.01$ ). The proportion $\mathrm{R}^{2}$ change $=0.033$ mean $3.3 \%$ increase in the variation was explained by the addition of the interaction term and it was statistically significant. Thus, it can be concluded that the dummy Additional Mathematics (took or did not take the subject) moderates the relationship between Modern Mathematics' grade point and total occurrences of mathematical errors.

TABLE II: Output of Moderated Regression Analysis

\begin{tabular}{|c|c|c|c|c|c|c|c|c|c|}
\hline \multicolumn{10}{|c|}{ Yödels summary } \\
\hline \multirow[b]{2}{*}{ Model } & \multirow[b]{2}{*}{$\mathrm{R}$} & \multirow[b]{2}{*}{$\begin{array}{r}\mathrm{R} \\
\text { Square }\end{array}$} & \multirow[b]{2}{*}{$\begin{array}{l}\text { Adjusted } \\
\text { Square }\end{array}$} & \multirow[b]{2}{*}{$\begin{array}{l}\text { Std. Error of } \\
\text { the Estimate }\end{array}$} & \multicolumn{5}{|c|}{ Change Statistics } \\
\hline & & & & & $\begin{array}{l}\text { R Square } \\
\text { Change }\end{array}$ & FChange & dfi & $d f_{2}$ & Sig. FChange \\
\hline 1 & $\begin{array}{l}.575 \\
. \quad 5\end{array}$ & 331 & .322 & 8.842 & .331 & 37.108 & & 50 & .000 \\
\hline 2 & b. & .364 & 352 & 8.647 & .033 & 7.820 & & 49 & .006 \\
\hline \multicolumn{10}{|c|}{ a. Predictors: (Constant), addmaths dummy, modmaths gradent } \\
\hline \multicolumn{10}{|c|}{ 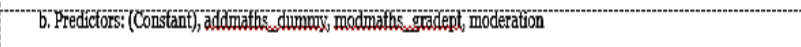 } \\
\hline \multicolumn{10}{|c|}{ c. Dependent Variable: fotales esmors } \\
\hline
\end{tabular}

The interaction plot shown in Figure 2 explains that total occurrences of mathematical errors were escalated among students who did not take Additional Mathematics during SPM. As for students with excellent, distinction and pass grades in Modern Mathematics and took Additional Mathematics exhibited errors ranging from 8.71 to 15.94 while students who did not take Additional Mathematics committed errors that ranged from 13.41 to 25.27. These figures reveal that students who did not take Additional Mathematics during SPM made more mathematical errors even if they scored a distinction or a pass for Modern Mathematics subject.

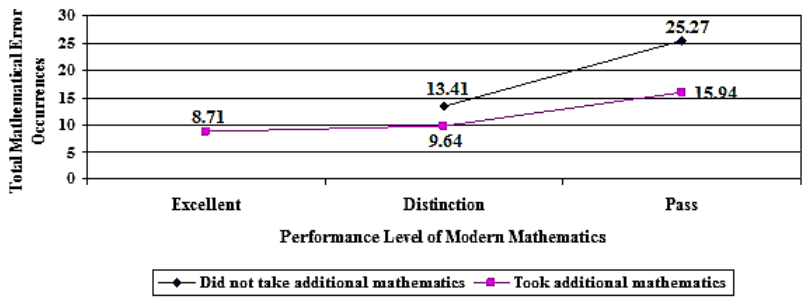

FIG 2 : The Moderation Effect of Additional

Mathematics on the Relationship Between Modern Mathematics Grades Point and Total Mathematical Error Occurrences

\section{SUMMARY}

As a conclusion, the exhibition of concept errors and transformation errors among students when answering MATo37 final examination paper are both significantly different across achievement levels in Modern Mathematics and Additional Mathematics. Furthermore, it was also noticed these both errors are more rampant among those less performing students. However, the exhibition of comprehension, number operation and factoring errors are approximately similar across the performance levels of Modern Mathematics and Additional Mathematics. For random, calculation and number form conversion errors, there was a significant difference in committing the errors between performance levels in Modern Mathematics. However, these three errors were noticed as similarities across performance levels in Additional Mathematics.

Based on the findings of this study, it can be concluded that students who took Additional Mathematics during SPM committed less mathematical errors as compared to those who did not take the subject. Thus, taking or not taking Additional Mathematics during SPM does moderate the relationship between Modern Mathematics grade point and total occurrences of mathematical errors during mathematics examination.

Hence, it is recommended that educators who are teaching Mathematics subjects adopted teaching strategies 
as suggested by Marzano (2000). He emphasized that error analysis is at the top of the higher-level thinking skills as the strategies required students to create, analyse, and even prove their claim. Teachers are considered as effective if only students are engaged in the learning processes. If students can find and explain errors in the learning process, then it shows that they really understand the concepts that are being used. It is recommended that further research is conducted by using the strategies as suggested by Marzano (2000).

\section{REFERENCES}

Andersson, U. \& Lyxell, B. 2007, Working memory deficit in children with mathematics difficulties: A general or specific deficit. Journal of Exceptional Children Psychology 96(3) 197-228.

Azrul Fahmi Ismail \& Marlina Ali 2007, Analisis Kesilapan DalamTajuk Ungkapan Algebra Di Kalangan Pelajar Tingkatan Empat. Buletin Persatuan Pendidikan Sains dan Matematik Johor Jilid 17 Bil. 1 Tahun 2007.

Geary, D.C. 2004, Mathematical and learning disabilities. Journal of Learning Disabilities 37(1): 4-15

IlmiFitroh Tun 'Isah. 2011, Analisis kesalahan dalam menyelesaikan soal matematika pokok bahasan lingkaran pada siswa kelas VIII SMP Negeri 14 Malang (TesisSarjana).

Ismail, N. A., \& Awang, H, 2008, Differentials in mathematics achievement among eighth-grade students in Malaysia. International Journal of Science, 6(3), 559571.doi: 10.1007/s10763-007-9109-4.

Ismail Radzuan. 2009, Model berfikir penyelesaian masalah matematik berayat murid tingkatan 5 yang berpencapaian tinggi dan rendah. Tesis Doktor Falsafah Pendidikan. UKM.

Latha M. N. 2007, Analysis of error in addition and subtraction of fraction among form 2 . Kertas Projek Sarjana Pendidikan. Universiti Malaya.

Maisurah Shamsuddin, Ahmad Zia Ul-Saufie Mohamad Japeri, Siti Balqis Mahlan, Norazah Umar \& FadzilawaniAstifar Alias 2014, Mathematical error by engineering student in calculus.Proceeding of 5 th International Conference on Science and Technology, 1(1), 118-122.
Marzano, R. J. 2000, Designing a new taxonomy of educational objectives. Thousand Oaks, CA: Corwin Press.

Miranda, F. 2006, How can you tell when your child has learning problems. $L D$ online. retrivedon 4 th Sep 2009. Retrieved from http://www.ldonline/

Mohd Zulfabli\& Siti Salwa 2014, Tahap Penguasaan Matematik Dalam Kursus Kejuruteraan di Politeknik. Prosiding 021CiE-TVET 2014 (pp. 328 342).

Muhammad Dliwaul Umam. 2014, Analisis kesalahan siswa dalam menyelesaikan soal cerita matematika materi operasih itung pecahan Jurnal Ilmiah Pendidikan Matematika, 3(3), 131-134.

Norhidayah Mohd Yusak\& Md Nor Bakar. 2007,. Mengenalpasti kesalahan pelajar dalam pembelajaran topi kungkapan algebra dan aplikasinya di kalangan pelajar tingkatan 4 (TesisSarjana Muda). Retrieved from http://merr.utm.my/10330/

Nik Azis Nik Pa 2008, Isu-isu kritikal dalam Pendidikan Matematik. Kuala Lumpur: PenerbitUniversiti Malaya.

Siti Balqis Mahlan, Noor 'Aina Abdul Razak, Maisurah Shamsuddin \&Fadzilawani Astifar Alias 2017, Kesalahan Pelajar dalam Asas Matematik: Kajian Kes Pelajar Pra-Diploma Perdagangan, UiTM CawanganPulau Pinang International Academic Research Journal of Social Science 3(1) 2017 Page 179-185

Siti Aishah Sheikh Abdullah \& Noor 'Aina Abd Razak. 
2005, Pola kesilapan matematik dalam kalangan pelajar tahun satu kejuruteraan. Seminar Matematik 2005, Pusat PengajianMatematik, UiTM Shah Alam, 6065. 